\title{
Effect of Low-N Stress on Performance and Combining Ability for Grain Yield and Quality Traits of Wheat Parents and their $F_{2}$ Progenies
}

\author{
A. M. M. Al-Naggar ${ }^{1}$, R. Shabana ${ }^{2}$, M. M. Abd El-Aleem ${ }^{3}$ and Zainab El-Rashidy ${ }^{4}$ \\ ${ }^{1}$ Department of Agronomy, Faculty of Agriculture, Cairo University, Giza, Egypt \\ ${ }^{2}$ Wheat Research Department, FCRI, Agricultural Research Centre (ARC), Giza, Egypt
}

\begin{abstract}
Developing high-yielding wheat varieties under low- $\mathrm{N}$ requires adequate information on the nature of combining ability of available genotypes and the types of gene actions involved in the expression of grain yield and quality traits under such low-N stress. The objective of present study was to get information about performance and general (GCA) and specific (SCA) combining ability variances and effects for grain yield and quality traits of wheat to help its improvement under low- $\mathrm{N}$ environment. Two experiments were conducted during two seasons, the $1^{\text {st }}$ under high- $\mathrm{N}(75 \mathrm{~kg} \mathrm{~N} / \mathrm{fed})$ and the $2^{\text {nd }}$ under low- $\mathrm{N}(0 \mathrm{~kg} \mathrm{~N} / \mathrm{fed})$ using a randomized complete block design with three replications. The entries included six Egyptian wheat genotypes differing in low-N tolerance and their $\mathrm{F}_{2}$ diallel crosses (without reciprocals). Data analyzed across seasons indicated that L25, L26 and L27 had high values of grain yield and quality traits and showed the best GCA effects for these traits. Under low-N, the best $\mathrm{F}_{2}$ crosses in per se performance and in SCA effects were L25 x L27, L25 x L26 and L26 x G168. Mean squares due to both GCA and SCA were significant under both low-N and high-N for all studied traits, but the magnitude of GCA was greater than SCA, indicating that additive is more important than non-additive genetic variance in controlling the inheritance of all studied grain yield and quality traits. The results indicated that under low-N and high-N, the mean performance of a given parent is an indication of its general combining ability and the mean performance of a given $\mathrm{F}_{2}$ cross is an indication of its specific combining ability effects for all studied grain yield and quality traits.
\end{abstract}

Keywords: Grain protein, Triticum aestivum, combining ability, Correlation, Low-N, Yield

\section{INTRODUCTION}

Wheat (Triticum aestivum L.) is one of the oldest and most important cereal crops in Egypt. Although wheat productivity in Egypt has increased during the past years, wheat production supplies only $45 \%$ of its annual domestic demand. Egypt still is one of the largest countries that import wheat. Wheat imports in 2011 were about 9.8 million tons, with a cost of about 3.2 billion US\$ (FAOSTAT, 2011). Therefore, Egypt needs to make a great effort to increase wheat production. Extending wheat growing outside the Nile Valley is the first effort toward overcoming wheat problems. However, most of the area outside the Nile Valley suffers from some abiotic stresses, the most important are nutrient deficiency and low water holding capacity; therefore increasing tolerance of wheat genotypes to such stresses, is one of the cheapest methods to spread growing wheat in these areas.

Crop performance is a function of the genotype and the nature of the production environment (Cooper and Byth, 1996). Genotypic differences for grain yield observed in the absence of stress are largely unrelated to differences observed in the presence of severe stress (Banziger et al., 1997; Ceccarelli, 1989; Ceccarelli and Grando, 1991; Ceccarelli et al., 1992 and Mosisa, 2005). This may indicate that different physiological mechanisms are associated with high yield in favorable conditions and high yield in unfavorable conditions (Blum, 1997; Ccccarelli, 1996). Variation for quantitative characters is under the control of many genes and the contribution of the genes can differ among environments (Basford and Cooper, 1998; Delacy et al., 1996 and Meseka et al.,2006). This conditional contribution of genes is the basis of genotype-by-environment ( $\mathrm{G} \times \mathrm{E})$ interactions.

Low-N stress is among the major abiotic stresses causing yield reductions in wheat (Lafitte and Edmeades, 1994; Beck et al., 1996; Banziger et al., 2000 and Banziger and Meyer, 2002). Understanding the genetic basis of hybrid performance under this stress is crucial to the design of appropriate breeding strategies (Hallauer and Miranda, 1988 and Betran et al., 2003 a,b). Although improved $\mathrm{N}$ efficiency has been a desirable goal of wheat breeders, the

${ }^{\text {I} C o r r e s p o n d i n g ~ A u t h o r: ~ m e d h a t a l n a g g a r @ g m a i l . c o m ~}$ 
information available regarding the relative contribution of general combining ability (GCA) effects and specific combining ability (SCA) effects for different traits related to grain yield under low-N is limited (Dass et al., 1997 and Gorny et al., 2011). Below et al. (1997) evaluated hybrids from a diallel mating design under high and low N availability (where low-N stress results in approximately 35\% yield reduction) in a temperate environment and reported that the mean squares for general combining ability (GCA) and specific combining ability (SCA) were significant for all traits measured at both levels of $\mathrm{N}$. They concluded that, based on the magnitude of the difference between GCA and SCA mean squares, the majority of the genetic effects were associated with GCA, indicative of additive genetic effects. Kling et al. (1997) conducted a diallel experiment in the tropical lowlands of West Africa for one season under high and low $\mathrm{N}$ conditions and reported that GCA for grain yield was significant under both $\mathrm{N}$ treatments while SCA was only significant under high-N. However, non-additive gene effects under low-N were common in other studies. Betran et al. (2003a) evaluated diallel crosses under high-N and low-N for one season and reported that under low-N, non additive genetic effects were more important for grain yield than the additive genetic effects. A significant crossover interaction was observed between the GCA of lines under low and high N conditions. Similar results were reported by Lafitte and Edmeades (1995). Banziger et al. (1997) found that N stress severity influenced genotype-by-N stress interactions. In addition to other environmental effects and type of families used, the contradictory results of different researchers may, therefore, be due to differences in the $\mathrm{N}$ stress level (testing environment) under which the genotypes were evaluated and/or genotypic difference among sets of genotypes included in the studies. A detailed study of the relative importance of GCA effects and SCA effects under contrasting $\mathrm{N}$ environments is crucial to generate precise information and design breeding strategies that serve the interests of resource-poor farmers (Banziger et al., 2000).

Gorny et al. (2011) reported that the soil N-treatments imposed had a substantial influence on gene actions responsible for the grain yield and $\mathrm{N}$ efficiency components and modes of inheritance. They found that under high $\mathrm{N}$-fertilization, the grain yield components were inherited in a manner favorable for wheat selection (preponderance of additive effects), while the enhanced contribution of non-additive gene effects and increased dominance under Nlimited conditions could impede wheat selection to improve the $\mathrm{N}$ efficiency and adaptation to less luxurious fertilization regimes. They concluded that selection methods that eliminate masking non-additive influences and take advantage of the additive variance should be employed to improve these traits.

This study aimed to determine per se performance of six Egyptian wheat parents and their $15 \mathrm{~F}_{2}$ diallel crosses, estimate the relative importance of their GCA and SCA under contrasting $\mathrm{N}$ environments and investigate the relationship between per se performance and combining ability of parents and $\mathrm{F}_{2}$ crosses.

\section{MATerials AND MethodS}

This study was carried out at Giza Research Station of the Agricultural Research Center (ARC), Giza Egypt (30 ${ }^{\circ}$ $02^{\prime} \mathrm{N}$ latitude and $31^{\circ} 13^{\prime} \mathrm{E}$ longitude with an altitude of 22.50 meters above sea level), in 2005/2006 season and at Noubarya Research Station of the ARC, Noubarya, Egypt $\left(30^{\circ} 66^{\prime} \mathrm{N}\right.$ latitude and $30^{\circ} 06^{\prime} \mathrm{E}$ longitude with an altitude of 15.00 meters above sea level), in 2006/2007, 2007/2008 and 2008/2009 seasons.

\subsection{Materials:}

Six bread wheat genotypes (Triticum aestivum L.) were chosen for their divergence in tolerance to low nitrogen, based on previous field screening carried out by Wheat Res. Dept., Field Crops Res. Inst., ARC, Egypt (Table 1).

Table1. Designation, pedigree and tolerance to low- $N$ of the six promosing lines and Egyptian cultivars of wheat used for making diallel crosses of this study

\begin{tabular}{|l|l|l|}
\hline Designation & Pedigree & Tolerance to low nitrogen \\
\hline Line 25(L25) & MYNA/VUL//TURACO/3/TURACO/4/Gem7. & Tolerant \\
\hline Line 26(L26) & MUNIA/CHTO//AMSEL. & Tolerant \\
\hline Line27(L27) & Compact-2/Sakha//Sakha61. & Tolerant \\
\hline Gemeiza(Gem7) & CMH74A.630/SX//Seri82/3/Agent. & Sensitive \\
\hline Gemeiza9(Gem9) & Ald "s"/HUC "s;//CMH74A.630/SX. & Sensitive \\
\hline Giza168(Gz168) & MRL/BUC//Seri. & Sensitive \\
\hline
\end{tabular}

Source. Wheat Res. Dept., Field Crops Res. Inst., ARC. Egypt 


\subsection{Making the F1 and F2 Diallel Crosses}

In season 2005/2006, a half diallel of crosses involving the six parents (without reciprocals) was done at Giza Agric. Res. Stat., Agric. Res. Center, to obtain the $F_{1}$ seeds of 15 crosses. In summer 2006, a part of $F_{1}$ seeds was sown in greenhouse of Wheat Res. Dept. under controlled conditions to obtain the $F_{2}$ seeds. In season 2007/2008, the half diallel of crosses was again done to increase quantity of $F_{1}$ seeds and in summer 2007 the $F_{1}$ seeds were again sown in the greenhouse under controlled conditions to obtain more seeds of $15 \mathrm{~F}_{2}$ crosses

\subsection{Field Evaluation of 6 Parents and 15 F2's}

In the seasons $2007 / 2008,2008 / 2009$, parents $(6)$ and $F_{2}$ 's (15) were sown on $17^{\text {th }}$ of November each season in the field of Noubarya Res. Stat., in two experiments under two levels of nitrogen fertilizer; each experiment under one level of nitrogen. The low level (low-N) was without fertilization, i.e. $0 \mathrm{~kg} \mathrm{~N} /$ feddan (LN) and the high level (high$\mathrm{N}$ ) was $75 \mathrm{~kg}$ Nitrogen/ feddan (HN); this is the recommended level of Ministry of Agriculture (one feddan $=4200$ $\mathrm{m}^{2}$ ). This level of nitrogen fertilizer ( equals $168 \mathrm{~kg}$ Urea/fed) was added in two equal doses, the first dose was added just before the sowing irrigation and the second dose just before the second irrigation (21 days after irrigation). In this experiment, a randomized complete block design (RCBD) was used with three replications. Each parent was sown in two rows and each $\mathrm{F}_{2}$ was sown in four rows; each row was three meter long; spaces between rows were $30 \mathrm{~cm}$ and $10 \mathrm{~cm}$ between plants, and the plot size was $1.8 \mathrm{~m}^{2}$ for parent and $3.6 \mathrm{~m}^{2}$ for $\mathrm{F}_{2}$. All other agricultural practices were done according to the recommendation of Ministry of Agriculture for growing wheat in Noubarya region.

Available soil nitrogen in $30 \mathrm{~cm}$ depth was analyzed immediately prior to sowing and $\mathrm{N}$ application at the laboratories of Water and Environment Unit, ARC, Egypt in the two seasons. Soil nitrogen was found to be 55 and $57 \mathrm{~kg} \mathrm{~N} / \mathrm{fed}$ in the seasons 2007/2008, 2008/2009, respectively. The soil analysis of the experimental soil at Noubarya Research Station, as an average of the two growing seasons, indicated that the soil is sandy loam $(67.86 \%$ sand, $7.00 \%$ silt and $25.14 \%$ clay), the $\mathrm{pH}$ is 8.93 , the EC is $0.55 \mathrm{dSm}^{-1}$, the soluble cations in meq $\mathrm{l}^{-1}$ are $\mathrm{Ca}^{2+}$ (5.30), $\mathrm{K}^{+}(0.70), \mathrm{Na}^{+}(0.31), \mathrm{Mg}^{2+}(2.60)$ and the soluble anions in meq $\mathrm{l}^{-1}$ are $\mathrm{CO}_{3}{ }^{2-}(0.00), \mathrm{HCO}_{3}^{-}(2.10), \mathrm{Cl}^{-}$ (5.30) and $\mathrm{SO}_{3}{ }^{2-}(1.51)$. All other agricultural practices were followed according to the recommendations of ARC, Egypt.

\subsection{Data Collection}

The following characteristics were measured on a random sample of 10 plants of each genotype of parents and 30 plants of $\quad F_{2}$ 's. 1. Number of spikes/plant (SPP): Number of fertile spikes per plant. 2. Number of grains $\backslash$ spike (GPS): Number of grains per spike. 3.100 grain weight (100GW) in g measured as weight of 100 grains taken from each guarded plant. 4. Grain yield/ plant (GYPP) in g measured as weight of the grains of each individual plant. 5. Harvest index (HI\%) according formula: HI= 100 (GYPP/ BYPP), where BYPP= biological yield/plant. 6. Grain protein content (GPC) measured as follows: $\mathbf{G P C} \%=\mathrm{N}_{\mathrm{g}} \times 5.7$ according to AACC (2000), where $\mathrm{N}_{\mathrm{g}}$ is grain nitrogen content. Grain $\mathrm{N}_{\mathrm{g}}$ was determined using Kjeldahl procedure according to A.O.A.C. (1990).

\subsection{Statistical and Genetic Analyses}

Each environment (HN and LN) was analyzed separately across seasons as RCBD for the purpose of determining genetic parameters using GENSTAT $10^{\text {th }}$ addition windows software. Least significant differences (LSD) values were calculated to test the significance of differences between means according to Steel et al. (1997). Diallel crosses in $\mathrm{F}_{2}$ generation were analyzed to obtain general (GCA) and specific (SCA) combining ability variances and effects for studied traits according to Griffing (1956) model I, i.e. fixed model, method II. Estimates of both general $\left(\delta_{\mathrm{g}}^{2}\right)$ and specific $\left(\delta_{\mathrm{s}}^{2}\right)$ combining ability variances were calculated as shown in Singh and Chaudhary (1985). Rank correlation coefficients calculated between per se performance of parents and their GCA effects in $\mathrm{F}_{2}$ 's; between per se performance of $\mathrm{F}_{2}$ crosses and their $\mathrm{SCA}_{\mathrm{F} 2}$ effects for studied traits under each environment across two seasons, using SPSS 17 computer software and the significance of the rank correlation coefficient was tested according to Steel et al. (1997). The correlation coefficient $\left(\mathrm{r}_{\mathrm{s}}\right)$ was estimated for each pair of any two parameters as follows: $\mathrm{r}_{\mathrm{s}}=$ 1- $\left(6 \Sigma d_{i}^{2}\right) /\left(n^{3}-n\right)$. Where, $d_{i}$ is the difference between the ranks of the $i^{\text {th }}$ genotype for any two parameters, $n$ is the number of pairs of data. The hypothesis Ho: $r_{s}=0$ was tested by the $r$-test with $(n-2)$ degrees of freedom.

\section{RESULTS AND DISCUSSION}

\subsection{Mean Performance}

A comparative summary of means of all studied traits across all 21 genotypes ( 6 parents and $15 \mathrm{~F}_{2}$ 's) subjected to two levels of nitrogen conditions and across two years is presented in Table (2). In general, low N caused a significant reduction in all studied traits, namely GYPP, SPP, 100GW, GPS, HI and GPC. Mean grain yield/plant 
(GYPP) was significantly decreased due to low-N by an average of 18.96 , and $15.40 \%$ for parents and $\mathrm{F}_{2}$ 's, respectively. Reduction in grain yield of wheat due to low soil nitrogen was reported by several investigators. A positive relationship between $\mathrm{N}$ application levels and the grain yield has already been shown in many studies (Austin et al., 1980; Desai and Bahatia, 1979). Significant reduction in grain yield as a result of low-N was associated with significant reductions in all yield components traits, i.e. SPP, 100GW and GPS. These reductions were relatively high in magnitude for number of spikes/ plant (SPP) for parents (23.65\%) and $\mathrm{F}_{2}$ 's (43.52\%). This indicates that SPP is the most determining component of grain yield / plant of wheat under low-N stress. The importance of this trait (number of spikes or fertile tillers per plant) in wheat for grain productivity under abiotic stress conditions was previously reported by several investigators (Al-Naggar et al., 2004,2007, 2011, and 2015 a,b,c). Geleto et al. (1995) reported that grain yield is closely related to the number of spikes per unit area. Fertilized plots produced more spikes than control. Such response can be attributed to the adequate nitrogen availability which might facilitate the tillering ability of plants, resulting in a greater spike population. Ayoub et al. (1994) also reported that spike population increased with increase in nitrogen level.

Table2. Means of studied wheat traits under low $-N(0 \mathrm{Kg} N / f e d)$ and high-N $(75 \mathrm{Kg} N / f e d)$ and relative reduction compared to high-N combined across parents and $F_{2}$ 's across two seasons

\begin{tabular}{|c|c|c|c|c|c|}
\hline \multirow[t]{2}{*}{ Traits } & \multirow[t]{2}{*}{ Parameter } & \multicolumn{2}{|l|}{ Parents } & \multicolumn{2}{|c|}{$F_{2}$ crosses } \\
\hline & & High-N & Low-N & High-N & Low-N \\
\hline \multirow{2}{*}{ GPS } & Average & 80.23 & 69.81 & 74.48 & 64.78 \\
\hline & Reduction $\%$ & --- & $13.47 * *$ & --- & $12.47 * *$ \\
\hline \multirow{2}{*}{$100 \mathrm{GW}(\mathrm{g})$} & Average & 4.66 & 4.05 & 3.37 & 2.61 \\
\hline & Reduction\% & --- & $12.96 * *$ & $\begin{array}{l}-- \\
-\end{array}$ & $21.72 * *$ \\
\hline \multirow{2}{*}{ SPP } & Average & 11.88 & 9.11 & 12.95 & 7.31 \\
\hline & Reduction $\%$ & --- & $18.96^{* *}$ & --- & $43.52^{* * *}$ \\
\hline \multirow{2}{*}{ GYPP(g) } & Average & 27.53 & 22.41 & 25.65 & 21.54 \\
\hline & Reduction \% & --- & $18.96^{* *}$ & --- & $15.40 * *$ \\
\hline \multirow{2}{*}{ HI $(\%)$} & Average & 43.67 & 40.73 & 43.50 & 41.37 \\
\hline & Reduction $\%$ & ---- & $6.57 * *$ & --- & 3.96 \\
\hline \multirow{2}{*}{$\operatorname{GPC}(\%)$} & Average & 16.18 & 12.12 & 14.04 & 13.83 \\
\hline & Reduction $\%$ & ------ & $25.06^{* *}$ & ------ & $23.31 * *$ \\
\hline
\end{tabular}

$\mathbf{N}=$ nitrogen, * and ${ }^{* *}$ indicate significance at 0.05 and 0.01 probability levels, respectively. Reduction\%= $100[(H N-L N) / H N]$

Moreover, low nitrogen caused a significant reduction in biological yield / plant (BYPP) by 12.49 and $11.24 \%$, grain protein content (GPC) by 25.06 and $23.31 \%$ and harvest index (HI) by 6.57 and $3.69 \%$ for parents and $\mathrm{F}_{2}$ 's, respectively.

Means of each parent, and $\mathrm{F}_{2}$ cross for studied traits under two nitrogen levels ( 0 and $\left.75 \mathrm{~kg} \mathrm{~N} / \mathrm{Fed}\right)$ across two seasons are presented in Table (3). In general means of all studied grain yield traits and grain protein content and of the three parents L25, L26 and L27 were higher in magnitude than those of the three other parents Gem 7, Gem 9 and Giza 168 under both high-N and low-N levels. Reduction in GYPP, due to low-N stress was lower in the first three parents than that in the latter parents. The first three parents (L25, L25 and L27) were therefore considered as low-N tolerant (N-efficient) genotypes and the latter ones (Gem 7, Gem 9 and Giza 168) as low-N sensitive (N inefficient) parents. These parents are therefore proper genetic material for diallel analysis for studying inheritance of adaptive traits for low-N tolerance in wheat.

The rank of crosses in $\mathrm{F}_{2}$ generation for most studied traits was changed from one environment (N-level) to another. The highest mean of GYPP under low-N was obtained from L25 x L27 followed by L25 x L26 and L26 x Gz168 in $\mathrm{F}_{2}$ generation. These crosses also showed the lowest reduction due to low-N stress, and therefore were considered tolerant (efficient) to low-N stress.

Table3. Mean performance of parents and $F_{2}$ 's under high-and low-levels of nitrogen across two years for studied traits

\begin{tabular}{|c|c|c|c|c|c|c|c|c|c|}
\hline & \multicolumn{3}{|l|}{ GPS } & \multicolumn{3}{|c|}{$100 G W(g)$} & \multicolumn{3}{|l|}{ SPP } \\
\hline & High N & Low N & Red\% & High N & Low N & Red\% & High $\mathbf{N}$ & Low N & Red\% \\
\hline & Parents & & & & & & & & \\
\hline L25 & 91.29 & 81.02 & $11.24 * *$ & 5.58 & 4.57 & $18.14 * *$ & 13.43 & 10.83 & $19.35 * *$ \\
\hline
\end{tabular}


American Research Journal of Agriculture, Volume 1, Issue 2, April 2015 ISSN 2378-9018

\begin{tabular}{|c|c|c|c|c|c|c|c|c|c|}
\hline L26 & 87.50 & 76.85 & $12.18 * *$ & 5.22 & 4.37 & $16.25 * *$ & 12.43 & 10.93 & $12.06 * *$ \\
\hline L27 & 96.02 & 89.08 & $7.23 * *$ & 5.17 & 4.92 & $4.99 * *$ & 12.22 & 10.85 & $11.19 * *$ \\
\hline Gem7 & 67.80 & 61.94 & $8.64 * *$ & 3.90 & 3.62 & $7.14 * *$ & 11.75 & 5.90 & $49.79 * *$ \\
\hline Gem9 & 69.52 & 51.68 & $25.66 * *$ & 3.99 & 3.40 & $14.68 * *$ & 10.52 & 7.32 & $30.43 * *$ \\
\hline Giza168 & 69.25 & 58.28 & $15.84 * *$ & 4.10 & 3.42 & $16.52 * *$ & 10.93 & 8.85 & $19.05 * *$ \\
\hline & \multicolumn{9}{|c|}{$\mathbf{F}_{2}$ crosses } \\
\hline L25 X L26 & 87.17 & 66.98 & $23.17 * *$ & 4.63 & 3.21 & $30.58 * *$ & 14.72 & 10.63 & $27.75 * *$ \\
\hline L25 X L27 & 92.23 & 77.73 & $15.73 * *$ & 4.35 & 3.70 & $15.08^{* * *}$ & 14.27 & 10.15 & $28.86 * *$ \\
\hline L25 X Gem 7 & 86.88 & 72.38 & $16.69 * *$ & 3.58 & 2.93 & $18.06 * *$ & 12.92 & 6.83 & $47.10 * *$ \\
\hline L25 X Gem 9 & 65.77 & 69.50 & $-5.67 *$ & 3.53 & 3.45 & $2.27 * *$ & 13.88 & 7.32 & $47.30 * *$ \\
\hline L25 X Gz 168 & 67.96 & 66.31 & 2.44 & 2.35 & 2.49 & $-5.74 * *$ & 13.78 & 7.57 & $45.10 * *$ \\
\hline L26 X L27 & 72.21 & 72.38 & -0.23 & 4.34 & 2.60 & $40.15 * *$ & 13.15 & 11.53 & $12.29 * *$ \\
\hline L26 X Gem 7 & 76.69 & 77.28 & -0.77 & 2.99 & 2.00 & $33.18^{* *}$ & 12.63 & 6.75 & $46.57 * *$ \\
\hline L26 X Gem 9 & 65.84 & 51.14 & $22.34 * *$ & 2.92 & 2.94 & $-0.46^{*}$ & 12.03 & 6.27 & $47.92 * *$ \\
\hline L26 X Gz 168 & 70.87 & 55.66 & $21.47 * *$ & 3.45 & 2.31 & $32.90 * *$ & 13.32 & 6.52 & $51.06 * *$ \\
\hline L27 X Gem 7 & 77.33 & 56.94 & $26.38 * *$ & 3.36 & 2.58 & $23.15^{* *}$ & 13.30 & 7.08 & $46.74 *$ \\
\hline L27 X Gem 9 & 83.33 & 72.06 & $13.52^{* * *}$ & 3.82 & 3.24 & $15.03 * *$ & 11.42 & 5.27 & $53.87 * 8$ \\
\hline L L27 X Gz168 & 77.69 & 60.77 & $21.78^{* *}$ & 3.34 & 1.96 & $41.39 * *$ & 13.62 & 5.03 & $63.04 * *$ \\
\hline Gem 7 X Gem9 & 61.89 & 74.07 & $-19.7 * *$ & 2.38 & 1.62 & $32.10^{* *}$ & 13.32 & 4.95 & $62.83 * *$ \\
\hline Gem 7 X Gz 168 & 62.25 & 46.16 & $25.85^{* * *}$ & 2.46 & 1.94 & $21.11 * *$ & 11.63 & 6.13 & $47.28 * *$ \\
\hline Gem 9 X Gz 168 & 69.02 & 52.42 & $24.05 * *$ & 3.05 & 2.22 & $26.98 * *$ & 10.27 & 7.68 & $25.16^{* *}$ \\
\hline L.S.D. ${ }_{0.05}(\mathrm{G})$ & 2.00 & 2.10 & & 0.49 & 0.39 & & 0.94 & 0.87 & \\
\hline$(\mathrm{N})$ & & & 4.00 & & & 0.80 & & & 1.30 \\
\hline$(\mathrm{GN})$ & & & 2.10 & & & 0.45 & & & 1.50 \\
\hline \multirow[t]{3}{*}{ Genotypes } & \multicolumn{3}{|c|}{ GYPP(g) } & \multicolumn{3}{|l|}{ HI $(\%)$} & \multicolumn{3}{|c|}{$\operatorname{GPC}(\%)$} \\
\hline & High $\mathrm{N}$ & Low $\mathbf{N}$ & $\operatorname{Red} \% \%$ & High N & Low N & Red\% & High $\mathbf{N}$ & Low N & Red\% \\
\hline & \multicolumn{9}{|l|}{ Parents } \\
\hline L25 & 26.48 & 25.39 & $4.1^{* *}$ & 39.74 & 41.06 & -3.33 & $13.6^{* *}$ & $11.7 * *$ & $13.59 * *$ \\
\hline L26 & 31.42 & 26.91 & $14.35^{* * *}$ & 45.95 & 44.16 & 3.89 & $15.7 * *$ & $14.2 * *$ & $9.86 * *$ \\
\hline L27 & 29.86 & 26.28 & $11.99 * *$ & 45.61 & 45.11 & 1.10 & $14.3 * *$ & $11.6 * *$ & $18.81^{* *}$ \\
\hline Gem 7 & 25.96 & 18.37 & $29.22 * *$ & 42.84 & 42.82 & 0.05 & $12.3 * *$ & $8.6^{*}$ & $30.43 * *$ \\
\hline Gem 9 & 25.76 & 17.89 & $30.53 * *$ & 40.79 & 33.49 & $17.88^{* * *}$ & $11.3^{* * *}$ & $6.8^{*}$ & $39.52 * *$ \\
\hline \multirow[t]{2}{*}{ Giza 168} & 25.71 & 19.65 & $23.57 * *$ & 47.12 & 37.77 & $19.85^{* *}$ & $11.1 * *$ & $8.9^{*}$ & $19.30 * *$ \\
\hline & \multicolumn{8}{|c|}{$\mathbf{F}_{2}$ crosses } & \\
\hline L25 X L26 & 25.96 & 24.97 & $3.81 * *$ & 42.52 & 42.62 & -0.23 & $16.5^{* *}$ & $12.0^{* * *}$ & $27.53 * *$ \\
\hline L25 X L27 & 23.94 & 26.09 & $-9.02 * *$ & 41.09 & 48.33 & $-17.64 * *$ & $12.0 * *$ & $12.7 * *$ & -5.45 \\
\hline L25 X Gem 7 & 23.33 & 23.88 & -2.36 & 39.97 & 53.21 & $-33.1 * *$ & $13.9 * *$ & $12.2 * *$ & $11.89 * *$ \\
\hline L25 X Gem 9 & 22.97 & 15.97 & $30.49 * *$ & 35.88 & 36.20 & -0.89 & $15.6^{* * *}$ & $12.5 * *$ & $20.10 * *$ \\
\hline L25 X Gz 168 & 27.08 & 21.75 & $19.71 * *$ & 42.14 & 35.30 & $16.23 * *$ & $17.9 * *$ & $12.5 * *$ & $29.91 * *$ \\
\hline L26 X L27 & 28.97 & 20.25 & $30.09 * *$ & 44.48 & 34.09 & $23.37 * *$ & $16.1^{* * *}$ & $11.7 * *$ & $27.33 * *$ \\
\hline L26 X Gem 7 & 23.95 & 23.51 & 1.84 & 36.58 & 40.19 & $-9.85 * *$ & $14.7 * *$ & $12.8 * *$ & $12.75 * *$ \\
\hline L26 X Gem 9 & 25.45 & 22.04 & $13.42 * *$ & 44.14 & 40.99 & $7.15 * *$ & $14.1 * *$ & $15.4 * *$ & $-9.48 * *$ \\
\hline L26 X Gz 168 & 31.84 & 24.03 & $24.52 * *$ & 54.07 & 43.71 & $19.17 * *$ & $13.8 * *$ & $15.9 * *$ & $-15.31 * *$ \\
\hline L27 X Gem 7 & 29.74 & 19.62 & $34.04 * *$ & 56.26 & 37.25 & $33.78 * *$ & $14.4 * *$ & $12.4 * *$ & $14.04 * *$ \\
\hline L27 X Gem 9 & 24.07 & 20.07 & $16.61 * *$ & 40.37 & 35.27 & $12.62 * *$ & $11.5 * *$ & $10.1^{* *}$ & $12.00 * *$ \\
\hline L27 X Gz168 & 26.21 & 23.39 & $10.77 * *$ & 43.90 & 44.32 & -0.96 & $10.0 * *$ & $9.5 * *$ & 5.50 \\
\hline Gem 7 X Gem9 & 25.41 & 19.18 & $24.50 * *$ & 45.78 & 46.85 & -2.34 & $8.3^{*}$ & $8.8^{*}$ & $-6.97 *$ \\
\hline Gem 7 X Gz 168 & 21.97 & 18.25 & $16.93 * *$ & 41.39 & 34.01 & 17.84 ** & $11.3 * *$ & $9.0^{* *}$ & $19.69 * *$ \\
\hline Gem 9 X Gz 168 & 23.88 & 20.16 & $15.57 * *$ & 43.98 & 48.25 & $-9.72 * *$ & $12.7 * *$ & $8.8^{*}$ & $30.60 * *$ \\
\hline L.S.D. ${ }_{0.05}(\mathrm{G})$ & 2.1 & 2.0 & & 3.8 & 4.0 & & 4.41 & 5.47 & \\
\hline$(\mathrm{N})$ & & & 2.5 & & & 3.0 & & & 10.03 \\
\hline$(\mathrm{GN})$ & & & 2.04 & & & 3.9 & & & 6.5 \\
\hline
\end{tabular}

* and ${ }^{* *}$ indicate significant at 0.05 and 0.01 probability levels, respectively 


\section{American Research Journal of Agriculture, Volume 1, Issue 3, 2015}

ISSN 2378-9018

On the contrary, the three crosses Gem 7 x Gem 9, Gem 7 x Gz168 and L27 x Gem 9 in $F_{2}$ generation showed the lowest GYPP under low-N and high reduction due to low-N and therefore were considered sensitive (inefficient) to low-N stress.

In general, $\mathrm{F}_{2}$-means for most characters were within the range of parental genotypes. Some $\mathrm{F}_{2}$ - progenies under $\mathrm{N}$ limited environment exhibited enhanced increased ability to accumulate protein in their grains, higher values of $\mathrm{HI}$ and SPP, suggesting transgressive effects in these characteristics. Gorny et al. (2011) reported a similar conclusion for grain dry weight produced per unit of $\mathrm{N}$ accumulated in grains $\left(\mathrm{G}_{\mathrm{W}} / \mathrm{N}_{\mathrm{g}}\right)$.

It is worthy to note that the magnitude of $\mathrm{N}$-induced alterations due to low-N stress in the majority of the studied traits was distinctly dependent upon the genotype, as evident by the significant genotype $\mathrm{x}$ environment interactions. These results are consistent with observations previously reported in wheat (El Bassam, 1998, Le Gouis et al. 2000 and 2002, Al-Naggar et al. 2004, 2007, 2011, 2015 a,b,c ), barley (Ceccarelli , 1994 and 1996 and Gorny and Sodkiewicz, 2001) and maize (Di Fonzo et al. 1982, Medici et al., 2004, Preseterl et al., 2008, Al-Naggar et al. 2011, 2014, 2015a,b ), corroborating that an evaluation of breeding materials under diverse fertilization regimes is necessary for choice of the most efficient parental forms and / or cross combinations, as suggested by BrancourtHulmel et al.(2005), Laperche et al. (2006), Dawson et al. (2008), Wolfe et al. (2008) and AL-Naggar et al. (2011, 2014, $2015 \mathrm{a}$ and b).

The rank of parents for GYPP was similar in the two N- environments, indicating less effect of interaction between parent and nitrogen level on GYPP. The three tolerant parents showed the highest GYPP under high-N and therefore were considered responsive parents. Moreover, L26 x Gz168 in $\mathrm{F}_{2}$ generation had the highest GYPP under high-N and therefore considered responsive crosses.

\subsection{Combining Ability Variances of F2's}

Analysis of variance of general (GCA) and specific (SCA) combining ability of $\mathrm{F}_{2}$ crosses of wheat for combined data across two years under high and low levels of nitrogen are presented in Table (4) for high- $\mathrm{N}$ and Table (5) for low-N. Mean squares due to genotypes were highly significant for all studied traits under the two levels of N. Results of $\mathrm{F}_{2}$ crosses show highly significant estimates of GCA and SCA mean squares under both high-N and low$\mathrm{N}$ for all studied traits.

Table4. Mean squares due to general (GCA) and specific (SCA) combining ability and their interactions with years ( $Y$ ) for studied traits in $F_{2}$ 's under high $N$ conditions across two years.

\begin{tabular}{|l|l|l|l|l|l|l|l|l|}
\hline SV & df & MS & \multicolumn{1}{l|}{} \\
\hline & & SPP & GPS & 100GW & GYPP & HI\% & GPC & \\
\hline Genotypes (G) & 20 & $12.77^{* *}$ & $670.95^{* *}$ & $5.03^{* *}$ & $45.54^{* *}$ & $140.44^{* *}$ & $1917.10^{* *}$ & \\
\hline GCA & 5 & $27.48^{* *}$ & $1806.64^{* *}$ & $8.91^{* *}$ & $79.92^{* *}$ & $178.97^{* *}$ & $5830.25^{* *}$ & \\
\hline SCA & 15 & $7.86^{* *}$ & $292.40^{* *}$ & $3.74^{* *}$ & $34.08^{* *}$ & $127.60^{* *}$ & $612.73^{* *}$ & \\
\hline GCA xY & 5 & $5.06^{* *}$ & $21.82^{* *}$ & 0.41 & $7.53^{* *}$ & $25.61^{* *}$ & $468.05^{* *}$ & \\
\hline SCA xY & 15 & $2.56^{* *}$ & $31.58^{* *}$ & 0.19 & $10.80^{* *}$ & $42.51^{* *}$ & $162.17^{* *}$ & \\
\hline GCA/SCA & & 3.49 & 6.18 & 2.30 & 2.35 & 1.40 & 9.52 & \\
\hline GCA xY /SCAxY & & 1.97 & 0.69 & 2.19 & 0.70 & 0.60 & 2.88 & \\
\hline error & 80 & 0.36 & 1.62 & 0.11 & 1.78 & 5.16 & 19.81 & \\
\hline
\end{tabular}

* and $* *$ indicate significant at 0.05 and 0.01 probability levels, respectively

The ratio GCA/SCA mean squares was greater than unity for all studied traits of $\mathrm{F}_{2}$ crosses under both high-N and low-N conditions, indicating that additive was larger in magnitude and more important than non-additive gene effects (dominance and epistasis) in controlling the inheritance of all studied traits under high-N and low $\mathrm{N}$ levels in the first segregating generation of the studied crosses.

These observations are in partial conflict with data reported by Le Gouis et al. (2002) who in N-limited diallel hybrids between modern French cultivars found markedly higher GCA/SCA ratios for grain yield, grain $\mathrm{N}$ yield and total above ground $\mathrm{N}$ than in those grown under high-N nutrition. More recently, a similar preponderance of GCA effects for grain yield was identified in $\mathrm{F}_{2}$ and $\mathrm{F}_{3}$ progenies of factorial hybrids between modern and exotic cultivars of barley grown under reduced $\mathrm{N}$ fertilization (Gorny and Ratajezak 2008). On the other hand, results of Gorny et al. (2011) on wheat appear to be in accord with similar N-shortage- induced increases in the importance of non-additive 
effects for grain yield previously reported in maize (Di Fonzo et al., 1982; Medici et al., 2004; Al-Naggar et al. 2011, 2015 a, b ) and those for grain yield in barley (Gorny and Sodkiewicz 2001).

Table5. Mean squares due to general (GCA) and specific (SCA) combining ability and their interactions with years ( $Y$ ) for studied traits in $F_{2}$ under low $N$ conditions across two years

\begin{tabular}{|l|l|l|l|l|l|l|l|l|}
\hline SV & df & \multicolumn{2}{l}{ MS } & \multicolumn{3}{l|}{} \\
\hline & & SPP & GPS & 100GW & GYPP & HI\% & GPC & \\
\hline Genotypes (G) & 20 & $27.77^{* *}$ & $789.82^{* *}$ & $4.89^{* *}$ & $60.04^{* *}$ & $182.02^{* *}$ & $1516.3^{* *}$ & \\
\hline GCA & 5 & $62.93^{* *}$ & $1792.94^{* *}$ & $6.37^{* *}$ & $150.04^{* *}$ & $61.93^{* *}$ & $2450.8^{* *}$ & \\
\hline SCA & 15 & $16.05^{* *}$ & $455.45^{* *}$ & $56.62^{* *}$ & $17.59^{* *}$ & $222.05^{* *}$ & $1204.8^{* *}$ & \\
\hline GCA xY & 5 & $5.06^{* *}$ & $93.53^{* *}$ & $4.94^{* *}$ & $14.87^{* *}$ & $67.16^{*}$ & 59.08 & \\
\hline SCA xY & 15 & $4.83^{* *}$ & $17.31^{* *}$ & $2.33^{* *}$ & $39.84^{* *}$ & $149.93^{* *}$ & 32.8 & \\
\hline GCA/SCA & & 3.92 & 3.94 & 0.11 & 8.53 & 0.28 & 2.03 & \\
\hline GCA xY /SCAxY & & 1.05 & 5.40 & 2.13 & 0.37 & 0.45 & 1.80 & \\
\hline error & 80 & 0.34 & 2.06 & 0.08 & 1.71 & 8.12 & 43.14 & \\
\hline
\end{tabular}

$*$ and $* *$ indicate significant at 0.05 and 0.01 probability levels, respectively

Results indicate that mean squares due to GCA x year and SCA x year interactions in $\mathrm{F}_{2}$ 's were significant or highly significant in the two levels of $\mathrm{N}$, except for $100 \mathrm{GW}$ under high-N and GPC under low-N, indicating that the additive and non-additive gene effects in most cases were affected by years.

The mean squares due to SCA $\mathrm{x}$ year were higher in magnitude than those due to GCA $\mathrm{x}$ year for all studied traits of $\mathrm{F}_{2}$ crosses, except for SPP and 100GW under high-N and SPP, GPS, 100GW and GPC under low-N, suggesting that in $\mathrm{F}_{2}$ crosses SCA (non-additive variance) is more affected by year than GCA for four traits (GYPP, GPS, HI nd GPC) under high-N and two traits (GYPP and HI) under low-N and GCA (additive variance) is more affected by year than SCA for other traits.

\subsection{GCA Effects Of Parents In F2 Crosses}

Estimates of general combining ability (GCA) effects calculated from the analysis of $\mathrm{F}_{2}$ diallel crosses under the two levels of $\mathrm{N}$ are presented in Tables (6 and 7). The best general combiners based on $\mathrm{F}_{2}$ diallel analysis were considered those having the highest positive GCA effects for the rest of studied $\mathrm{F}_{2}$ traits.

Table6. Estimates of general combining ability effects $\left(\hat{g}_{i}\right)$ of all traits in $F_{2}$ 's under high $N$ conditions across two years

\begin{tabular}{|l|l|l|l|l|l|l|l|}
\hline Parents & SPP & GPS & 100GW & GYPP & HI & GPC & \\
\hline L25 & $1.20^{* *}$ & $6.22^{*}$ & $0.43^{* *}$ & $-0.88^{*}$ & $-0.09^{*}$ & $-4.21^{* *}$ & \\
\hline L26 & $0.41^{*}$ & $1.87^{*}$ & $0.34^{* *}$ & $1.96^{* *}$ & $-0.06^{*}$ & $9.01^{* *}$ & \\
\hline L27 & 0.12 & $7.75^{* *}$ & $0.40^{* *}$ & $1.17^{* *}$ & $-0.04^{* *}$ & $13.04^{* *}$ & \\
\hline Gem 7 & -0.17 & $-4.03^{* *}$ & $-0.45^{* *}$ & $-0.87^{*}$ & -0.01 & $6.13^{* *}$ & \\
\hline Gem 9 & $-0.70^{* *}$ & $-5.99^{* *}$ & $-0.31^{* *}$ & $-1.25^{*}$ & $0.084^{*}$ & $-9.41^{* *}$ & \\
\hline Giza 168 & $-0.85^{* *}$ & $-5.82^{*}$ & $-0.41^{* *}$ & -0.11 & $0.12^{* *}$ & $-14.55^{* *}$ & \\
\hline SE $_{\mathrm{gi}}$ & 0.32 & 0.68 & 0.17 & 0.71 & 0.03 & 2.37 & \\
\hline SE $_{\mathrm{gi}-\mathrm{gi}}$ & 0.50 & 1.05 & 0.27 & 1.11 & 0.06 & 3.68 & \\
\hline
\end{tabular}

* and ${ }^{* *}$ indicate significant at 0.05 and 0.01 probability levels, respectively

Table7. Estimates of general combining ability effects $\left(\hat{g}_{i}\right)$ of all traits in $F_{2}$ 's under low $N$ conditions across two years

\begin{tabular}{|l|l|l|l|l|l|l|l|}
\hline Parents & SPP & GPS & 100GW & GYPP & HI & GPC & \\
\hline L25 & $1.17^{* *}$ & $6.43^{* *}$ & $0.47^{* *}$ & $1.36^{*}$ & 1.18 & $-4.91^{*}$ & \\
\hline L26 & $1.1^{* *}$ & $1.7^{* *}$ & 0.08 & $2.01^{*}$ & $0.20^{*}$ & $7.25^{* *}$ & \\
\hline L27 & $0.75^{*}$ & $6.81^{* *}$ & $0.34^{*}$ & $1.18^{*}$ & 0.14 & $10.44^{* *}$ & \\
\hline Gem 7 & $-1.41^{* *}$ & $-1.6^{*}$ & $-0.36^{*}$ & $-1.42^{*}$ & 1.10 & -1.27 & \\
\hline Gem 9 & $-1.1^{*}$ & $-5.1^{* *}$ & -0.11 & -2.42 & $-1.72^{*}$ & $-6.61^{* *}$ & \\
\hline Giza 168 $^{*}$ & $-0.52^{*}$ & $-8.2^{* *}$ & $-0.42^{* *}$ & $-0.71^{*}$ & -0.90 & $-4.89^{*}$ & \\
\hline SE $_{\mathbf{g i}}$ & 0.31 & 0.77 & 0.15 & 0.70 & 1.53 & 3.50 & \\
\hline SE $_{\text {gi-gi }}$ & 0.48 & 1.19 & 0.23 & 1.08 & 2.36 & 5.44 & \\
\hline
\end{tabular}

* and ** indicate significant at 0.05 and 0.01 probability levels, respectively 
Data in Table (6) indicate that under high-N, the best general combiners based on $\mathrm{F}_{2}$ diallel analysis were $\mathrm{L} 27$ for fou traits (GPS, 100GW, GYPP and GPC), L26 for five traits (SPP, GPS, 100GW, GYPP and GPC), L25 for three traits (SPP, GPS, and 100GW), and Gem7 for one trait (GPC).

Under low-N (Table 7), the best general combiners were L25 for seven traits (SPP, GPS, 100GW and GYPP), L26 for five traits (SPP, GPS, GYPP, HI, and GPC), L27 for five traits (SPP, GPS, 100GW, GYPP, and GPC). The best combiners identified from both $\mathrm{F}_{1}$ and $\mathrm{F}_{2}$ diallel analyses under high-N and low-N are more or less similar in most cases under low-N conditions. L25, L26 and L27 are generally the best combiners for most grain yield and quality traits based on diallel analyses of $F_{2}$ crosses. These parents are expected to have more additive genes for the respective characters

\subsection{SCA Effects Of F2's}

Specific combining ability (SCA) effects of the $\mathrm{F}_{2}$ crosses under two levels of $\mathrm{N}$ are presented in Tables (7 and 8). Under high-N, the best $\mathrm{F}_{2}$ cross in SCA effects was L27 x Gem 7 for three traits (GYPP, HI and GPC), L26 $\mathrm{x}$ Gz168 for two traits (GYPP and HI), Gem7 x Gem9 for two traits (GPS and HI) and Gem 9 x Gz168, and L25 x Gem7 for one trait (GPS)

Table8. Estimates of specific combining ability effects $\left(\hat{s}_{i j}\right)$ of $F_{2}$ 's under high $N$ conditions across two years

\begin{tabular}{|c|c|c|c|c|c|c|}
\hline Crosses & SPP & GPS & 100GW & GYPP & HI & GPC \\
\hline L25 X L26 & $1.03 *$ & $2.96^{*}$ & 0.12 & -1.31 & 0.84 & $9.49 * *$ \\
\hline L25 X L27 & 0.53 & $2.15^{*}$ & -0.21 & $-2.53 *$ & -1.05 & 4.92 \\
\hline L25 X Gem 7 & $-1.58^{*}$ & $8.57 * *$ & -0.14 & -1.1 & -0.71 & $-12.7 * *$ \\
\hline L25 X gem 9 & 0.55 & $-10.57 * *$ & -0.33 & -1.08 & -3.05 & -4.56 \\
\hline L25 X Gz 168 & 0.32 & $-8.56^{* *}$ & $-1.40^{* *}$ & 1.90 & -0.30 & -1.05 \\
\hline L26X L27 & 0.39 & $-13.52 * *$ & -0.13 & -0.40 & -1.73 & -3.20 \\
\hline L26X Gem 7 & -0.65 & $2.72 *$ & $-0.63 *$ & -3.32 & $-8.17 * *$ & 4.94 \\
\hline L26X Gem 9 & $-0.92 *$ & $-6.15^{* *}$ & $-0.84 *$ & -1.44 & 1.13 & $-12.32^{* * *}$ \\
\hline L26X Gz 168 & -0.15 & -1.30 & -0.21 & $3.80 *$ & $7.56^{* *}$ & 6.22 \\
\hline L27 X Gem 7 & -0.64 & $-2.51 *$ & -0.33 & $3.26^{*}$ & $11.05^{* *}$ & $11.19^{* * *}$ \\
\hline L27 X Gem 9 & $-1.29 *$ & $5.45 * *$ & -0.01 & $-2.04 *$ & $-3.10^{*}$ & 13.27 ** \\
\hline L27 X Gz168 & -0.003 & -0.36 & -0.38 & -1.03 & $-3.06^{*}$ & $8.38^{* *}$ \\
\hline Gem 7 X Gem9 & $2.44 *$ & $-4.21 * *$ & $-0.60 *$ & 1.35 & $3.77 *$ & 3.69 \\
\hline Gem7 X Gz 168 & -0.81 & $4.02 * *$ & -0.41 & $-3.23 *$ & $-4.12 *$ & $12.9 * *$ \\
\hline Gem9 X Gz 168 & $-1.70 *$ & $4.71 * *$ & 0.03 & -0.94 & 0.21 & -3.70 \\
\hline $\mathbf{S E}_{\mathrm{Sij}}$ & 0.89 & 1.87 & 0.48 & 1.96 & 3.34 & 6.54 \\
\hline $\mathbf{S E}_{\mathrm{Sij}}{ }^{-S i k}$ & 1.32 & 2.79 & 0.71 & 2.93 & 4.98 & 9.76 \\
\hline $\mathbf{S E}_{\mathrm{Sij}_{\mathrm{j}} \text {-Skl }}$ & 1.23 & 2.58 & 0.66 & 2.71 & 4.62 & 9.04 \\
\hline
\end{tabular}

*and** indicate significant at 0.05 and 0.01 probability levels, respectively

Under low-N, the best $\mathrm{F}_{2}$ cross for SCA effects was L25 x Gem 7 for two traits (GYPP and HI), Gem9 x Gz168 for SPP, L27 x Gem 9, for GPS and GPC and L27 x Gz168 for GPC. These $\mathrm{F}_{2}$ crosses and especially those showing high SCA effects and including one parent of high GCA effects are expected to release more transgressive segregants if additive gene effects existed in the high general combiner parent and epistasis acts in the cross in the same direction for decreasing the undesirable characters and increasing the desirable traits. Results of Gorny et al. (2011) on wheat $F_{2}$ crosses appear to be in accord with similar N-Shortage - induced increases in the importance of non - additive effects for grain yield and components of NUE previously reported in maize (Di Fonzo et al., 1982, Medici et al., 2004, Al-Naggar et al. 2015a) and those for grain yield under low-N in grain sorghum (Al-Naggar et al., 2008). Gorny et al. (2011) reported that under high $\mathrm{N}$-fertilization, the grain yield components were incanted in a manner favorable for wheat selection (preponderance of additive effects) however the enhanced contribution of non-additive gene effects and increased dominance under $\mathrm{N}$-limited conditions could impede wheat selection to improve the $\mathrm{N}$ efficiency and adaptation to less luxurious fertilization regimes. They concluded that selection methods that eliminate masking non-additive influences and take advantage of the additive variance should be employed to improve those traits. 
American Research Journal of Agriculture, Volume 1, Issue 2, April 2015

ISSN 2378-9018

Table9. Estimates of specific combining ability effects $\left(\hat{s}_{i j}\right)$ of $F_{2}$ 's under low $N$ conditions across two years

\begin{tabular}{|c|c|c|c|c|c|c|}
\hline Crosses & SPP & GPS & $100 \mathrm{GW}$ & GYPP & HI & GPC \\
\hline L25 X L26 & 0.54 & $-7.36^{*}$ & -0.36 & -0.19 & 0.06 & $16.62 * *$ \\
\hline L25 X L27 & 0.40 & -1.73 & -0.14 & 1.76 & $5.82 *$ & $\begin{array}{l}-3.73 \\
\end{array}$ \\
\hline L25 X Gem 7 & -0.76 & 1.34 & -0.20 & $2.15 * *$ & $9.74 *$ & $-12.50^{* *}$ \\
\hline L25 X Gem 9 & -0.60 & 1.99 & 0.07 & $-4.77 *$ & $-4.45^{*}$ & $-18.77 * *$ \\
\hline L25 X Gz 168 & $-0.91 *$ & 1.87 & $-0.58 *$ & -0.70 & $-6.17 *$ & $\begin{array}{l}-6.34 \\
\end{array}$ \\
\hline L26X L27 & $1.86^{*}$ & $-2.35^{*}$ & $-0.85^{*}$ & $-4.73 * *$ & $-7.45^{*}$ & -8.61 \\
\hline L26X Gem 7 & -0.79 & $10.97 * *$ & $-0.75^{*}$ & 1.13 & -2.30 & -0.11 \\
\hline L26X Gem 9 & $-1.57 *$ & $-11.66 * *$ & -0.05 & 0.65 & 1.32 & 7.09 \\
\hline L26X Gz 168 & $-1.89 *$ & $-4.05^{*}$ & $-0.37 *$ & 0.94 & 3.22 & 5.73 \\
\hline L27 X Gem 7 & -0.08 & $-14.49 * *$ & $-0.43 * *$ & $-1.93^{*}$ & $-5.18 *$ & 0.82 \\
\hline L27 X Gem 9 & $-2.22 *$ & $4.15^{*}$ & -0.01 & -0.48 & $-4.34 *$ & $23.47 * *$ \\
\hline L27 X Gz168 & $-3.02 *$ & $-10.25^{* *}$ & $-0.99 * *$ & 1.13 & 3.89 & $25.36^{* * *}$ \\
\hline Gem 7 X Gem9 & -0.39 & $14.57 * *$ & $-0.94 * *$ & 1.23 & $6.28 *$ & -0.59 \\
\hline Gem 7 X Gz 168 & 0.23 & $-10.25^{* *}$ & $-0.30^{*}$ & -1.41 & $-7.39 *$ & -6.50 \\
\hline Gem 9 X Gz 168 & $1.5^{*}$ & -0.47 & $-0.26^{*}$ & 1.50 & $9.69^{*}$ & -3.96 \\
\hline $\mathbf{S E}_{\mathrm{Sij}}$ & 0.85 & 2.11 & $0.41 *$ & 1.92 & 4.19 & 9.66 \\
\hline $\mathbf{S E}_{\mathrm{Sij}}{ }^{-S i k}$ & 1.27 & 3.15 & $0.61 *$ & 2.87 & 6.26 & 14.40 \\
\hline $\mathbf{S E}_{\mathrm{Sij}}-\mathrm{Skl}$ & 1.18 & 2.92 & $0.57 *$ & 2.66 & 5.79 & 13.34 \\
\hline
\end{tabular}

* and ${ }^{* *}$ indicate significant at 0.05 and 0.01 probability levels, respectively

\subsection{Correlations Between Xp And GCAF1 And Between XF2 And SCAF2 Effects}

Rank correlation coefficients calculated between mean performance of parents (Xp) and their GCA effects of $\mathrm{F}_{2}$ 's for studied grain yield and quality characters are presented in Table (9). Significant $(\mathrm{P} \leq 0.05$ or 0.01$)$ correlations between $\mathrm{Xp}$ and $\mathrm{GCA}_{\mathrm{F} 1}$ effects and between $\mathrm{Xp}$ and $\mathrm{GCA}_{\mathrm{F} 2}$ effects existed for all studied traits under both high-N and low-N, except for $\mathrm{HI}$ between $\mathrm{Xp}$ and $\mathrm{GCA}_{\mathrm{F} 2}$ under high-N conditions. In general, the magnitude of correlation coefficient between $\mathrm{Xp}$ and $\mathrm{GCA}_{\mathrm{F} 2}$ effects was very high (>0.93 in 8 out of 12 cases ) and was higher at low-N than high-N in 4 out of 6 traits. The highest correlation coefficient under low-N between Xp and GCA was observed for GYPP (0.98) and 0.97 for SPP, 0.93 for GPS and 0.89 for 100GW. On the contrary, the lowest correlation coefficient between Xp and GCA effects was shown under high-N for HI (0.25). These results indicate that the best performing parents for grain yield components are also the best general combiners and vice versa, and therefore, the mean performance of a given parent under low- $\mathrm{N}$ and high-N is an indication of its general combining ability. This conclusion was previously reported by Le Gouis et al., (2000) and Yildirim et al. (2007) in wheat and Meseka et al (2016) and Al-Naggar et al., (2015a) in maize. Le Gouis et al. (2000) reported that when GCA effects are largely superior to SCA effects, the correlation between per se value and GCA would give an indication about the possibility to use the means of the two parents to predict the value of hybrid. Yildirim et al. (2007) reported that per se values of parent for grain yield traits were positively correlated with GCA effects of themselves at N0 level; this can be used to obtain high $\mathrm{N}$ use efficient lines.

Table10. Rank correlation coefficients among means performance of parents $(X p)$ and their GCA effects for $F_{2}$ 's $\left(G C A_{F 2}\right)$ and between mean performance of $F_{2}$ 's $\left(X_{F 2}\right)$ and $S C A_{F 2}$ effects under high and low- $N$ environments across two seasons.

\begin{tabular}{|l|l|l|l|l|l|l|}
\hline Traits & \multicolumn{2}{|l|}{$\mathbf{X}_{\mathbf{P}} \boldsymbol{v} \mathbf{G C A}_{\mathbf{F 2}}$} & \multicolumn{3}{|l|}{$\mathbf{X}_{\mathbf{F 2}} \boldsymbol{v} \mathbf{S} \mathbf{S C A}_{\mathbf{F 2}}$} & \\
\hline & $\mathbf{H N}$ & $\mathbf{L N}$ & & & $\mathbf{H N}$ & $\mathbf{L N}$ \\
\hline SPP & $0.98^{* *}$ & $0.71^{* *}$ & & & $0.71^{* *}$ & $0.38^{* * *}$ \\
\hline GPS & $0.98^{* *}$ & $0.70^{* *}$ & & & $0.70^{* *}$ & 0.13 \\
\hline $\mathbf{1 0 0 G W}$ & $0.98^{* *}$ & $0.88^{* *}$ & & & $0.88^{* *}$ & $0.37^{* *}$ \\
\hline GYPP & $0.94^{* *}$ & $0.83^{* *}$ & & & $0.83^{* *}$ & 0.13 \\
\hline HI\% & 0.25 & $0.91^{* *}$ & & & $0.91^{* *}$ & -0.06 \\
\hline GPC & $0.77^{* *}$ & $0.32^{* *}$ & & & $0.32^{* *}$ & $0.34^{* * *}$ \\
\hline
\end{tabular}

* and ${ }^{* *}$ indicate significant at 0.05 and 0.01 probability levels, respectively 


\section{American Research Journal of Agriculture, Volume 1, Issue 3, 2015 ISSN 2378-9018}

For $\mathrm{F}_{2}$ crosses, under both low- $\mathrm{N}$ and high- $\mathrm{N}$, the correlation coefficient between mean performance of $\mathrm{F}_{2}$ 's $\left(\mathrm{X}_{\mathrm{F} 2}\right)$ and their $\mathrm{SCA}_{\mathrm{F} 2}$ effects were highly significant and positive; in all studied traits under high-N and SPP, 100GW and GPC under low-N (Table 9). This indicates that the mean performance of a given $\mathrm{F}_{2}$ cross could be used as an indication of its specific combining ability effects for all studied characters under high-N and SPP, 100GW and GPC under low-N. This conclusion was also reported by Le Gouis et al., (2000) and Yildirim et al. (2007) under low-N conditions.

Summarizing the above mentioned results, it cloud be concluded that low-N stress affects on the associations between mean performance of parents and $\mathrm{F}_{2}$ s on GCA and SCA effects of $F_{2}$, respectively and so conclusions generated from results under high-N differ from those generated from results under low-N. Only indication under high-N and low-N are similar for the association between mean performance of parents and their GCA effects for $\mathrm{F}_{2}$ $\left(\mathrm{GCA}_{\mathrm{F} 2}\right)$. Thus, under either low-N or high-N the mean performance of a given parent could be considered an indication of its general combining ability estimated from $\mathrm{F}_{2}$ 's. But under high-N only, the mean performance of a given $\mathrm{F}_{2}$ cross could be considered an indication of its SCA effects in $\mathrm{F}_{2}$ generation.

\section{CONCLUSIONS}

This study identified wheat genotypes (the promising lines L25, L26 and L27 and their $F_{2}$ crosses L25 x L27, L25 x L26 and L26 x G168 of high mean performance and combining ability effects for grain yield and quality traits under low-N conditions. These genotypes could be offered to wheat breeding programs for developing low-N tolerant varieties. Breeding programs that utilizes both additive and non-additive genetic variances could be used to improve grain yield and quality traits, with more emphasis on selection methods in segregating generations of wheat hybrids that utilize additive and additive $\mathrm{x}$ additive genetic components under low- $\mathrm{N}$ conditions. The results indicated that under low- $\mathrm{N}$ and high- $\mathrm{N}$, the mean performance of a given parent is an indication of its general combining ability and that the mean performance of a given $\mathrm{F}_{2}$ cross could be used as an indication of its specific combining ability effects for all studied grain yield component traits and grain protein content.

\section{REFERENCES}

[1] AACC (2000). American Association Cereal Chemists. Approved Methods of the American Association Cereal Chemists. American Association of Cereal Chemists, Inc., St. Paul, Minnesota.

[2] A.O.A.C.(1990). Official Methods of Association of Analytical Chemists. 15th ed. Washington D.C.,USA. 290p.

[3] Al- Naggar, A.M.M.; Shabana R.; Atta M.M.M. and Al-Khalil T.H. (2015a). Regression of Grain Yield of Maize Inbred Lines and Their Diallel Crosses on Elevated Levels of Soil-Nitrogen. International Journal of Plant \& Soil Science, Vol.4 (6): 499-512.

[4] Al- Naggar, A.M.M.; Shabana R.; Atta M.M.M. and Al-Khalil T.H. (2015b). Maize response to elevated plant density combined with lowered N-fertilizer rate is genotype-dependent. The Crop Journal, Vol. (3):96-109.

[5] Al- Naggar, A.M.M.; Shabana R.; Atta M.M.M. and Al-Khalil T.H. (2015c). Response of genetic parameters of low-N tolerance adaptive traits to decreasing soil-N rate in maize (Zea mays L.). Applied Science Reports, 9 (2): 110-122.

[6] Al- Naggar, A.M.M.; Atta M. M. M. and Amein M. M. (2009). Maize genotypic differences in nitrogen use efficiency under low soil-N conditions. Egypt. J. of Appl. Sci., 24(3B): 528-546.

[7] Al-Naggar, A.M.M.; R. Shabana and T. H. Al-Khalil (2010). Tolerance of 28 maize hybrids and populations to lownitrogen. Egypt. J. Plant Breed. 14(2): 103-114.

[8] Al- Naggar, A.M.M.; Shabana R.; Atta M.M.M. and Al-Khalil T.H. (2014). Genetic parameters controlling some maize adaptive traits to elevated plant densities combined with reduced N-rates. World Research Journal of Agronomy, Vol. 3, Issue $2: 70-82$.

[9] Al- Naggar, A.M. M.; El-Kadi D. A. and Abo-Zaid Zeinab S. A. (2006). Genetic parameters of grain sorghum traits contributing to low - N tolerance. Egypt. J. Plant Breed. 10 (2) :79-102.

[10] Al- Naggar, A. M. M.; El-Kadi D. A. and Abo-Zaid Zeinab S. A. (2007).. Inheritance of nitrogen use efficiency traits in grain sorghum under low- and high-N. Egypt. J. Plant Breed. 11 (3): 181-206.

[11] Al-Naggar, A.M.M.; Ragab A.E.I., Youssef S. S. and Al-Bakry R. I. M. (2004). New genetic variation in drought tolerance induced via irradiation and hybridization of Egyptian cultivars of bread wheat. Egypt. J. Plant Breed. 8:353-370.

[12] Al-Naggar, A. M. M. and Shehab- El- Deen, M.T. (2012). Predicted and actual gain from selection for early maturing and high yielding wheat genotypes under water stress conditions. Egypt. J. Plant Breed. 16 (3) : 73 -92.

[13] Austin, R.B., Bingham J., Blackwell R.D., Evans L.T., Ford M.A., Morgan C.L., Taylor M. (1980). Genetic improvements in winter wheat yields since 1900 and associated physiological changes. Journal of Agricultural Science. 94: 675-689.

[14] Ayoub, M., Guertin, S., Smith, D. L. 1995. Nitrogen fertilizer rate and timing effect on bread wheat protein in eastern Canada. Crop Sci. 174, 337-349. 
[15] Bänziger M., F.J. Betrán, H.R. Lafitte, 1997 Efficiency of high nitrogen selection environments for improving maize forlow-nitrogen target environments. Crop Sci. 37: 1103-1109.

[16] Bänziger M., G.O. Edmeades, D. Beck, M. Bellon, 2000 Breeding for Drought and N Stress Tolerance in Maize: From Theory to Practice. CIMMYT, Mexico, D.F

[17] Bänziger M., J.D. Meyer, 2002 Collaborative maize variety development for stress prone environments in Southern Africa Farmers, Scientists and Plant Breeding. pp. 269-296. CAB International,London.

[18] Basford K.E., M. Cooper, 1998 Genotype-by-environment interactions and some considerations of their implications for wheat breeding in Australia. Aust. J. Agric. Res. 49: 153-174.

[19] Beck D.L., J. Betran, M. Bänziger, G.O. Edmeades, J.M. Ribaut, M. Willcox, S.K. Vasal, A. Ortega, 1996 Progress in developing drought and low soil $\mathrm{N}$ tolerance in maize. pp. 85-111. In: D. Wilkinson (Ed.), Proc. 51st Annual Corn and Sorghum Research Conf., Chicago, 10-11 Dec. 1996. ASTA, Washington,DC.

[20] Below F.E., P.S. Brandau, R.J. Lambert, R.H. Teyker, 1997 Combining ability for nitrogen use in maize. pp. 316-319. In: G.O.Edmeades, M. Bänziger, H.R. Mickelson, C.B. Pena-Valdiva (Eds.), Developing Drought and Low N-Tolerant Maize. Proc. Symposium, March 25-29, 1996. CIMMYT, El Batan, Mexico. Mexico, D.F.: CIMMYT.

[21] Betrán F.J., D. Beck, M. Bänziger, G.O. Edmeades, 2003a Genetic analysis of inbred and hybrid grain yield under stress and non-stress environments in tropical maize. Crop Sci. 43: 807-817.

[22] Betrán F.J., D. Beck, M. Bänziger, G.O. Edmeades, 2003b Secondary traits in parental inbreds and hybrids under stress and non-stress environments in tropical maize. Field Crops Res. 83: 51-65.

[23] Blum, A., 1997 Constitutive traits affecting plant performance under stress. pp. 131-135. In: G.O. Edmeades, M. Bänziger, H.R. Mickelson, C.B. Pena-Valdivia (Eds.), Developing Drought and Low-N Tolerant Maize. Proc. Symposium, 25-29 March 1996. Elbatan, Mexico, CIMMYT, Mexico, D.F.

[24] Brancourt-Hulmel, M., Heumez E., Pluchard P., Beghin D., Depatureaux C., Giraud A and, Le Gouis J. (2005). Indirect versus direct selection of winter wheat for low-input or high-input levels. Crop Sci. 45:1427-1431.

[25] Ceccarelli S., 1996 Adaptation to low /high input cultivation. Euphytica 92: 203-214.

[26] Ceccarelli, S. (1994). Specific adaptation and breeding for marginal conditions. Euphytica 77:205-219.

[27] Ceccarelli S., S. Grando, 1991 Environment of selection and type of germplasm in barley breeding for low- yielding conditions. Euphytica 57: 207-219.

[28] Ceccarelli, S., S. Grando, J. Hamblin, 1992 Relationship between barley grain yield measured in low and high yielding environments. Euphytica 64: 49-58.

[29] Cooper, M., D.E. Byth, 1996 Understanding plant adaptation to achieve systematic applied crop improvement: A fundamental challenge. pp. 5-23. CAB International and IRRI, UK.

[30] Dass, S., Y.P. Dang, A.K. Dhawan, N.N. Singh, S. Kumar, 1997 Morho-physiological basis for breeding drought and low$\mathrm{N}$ tolerant maize genotypes in India. pp. 106-111. In: G.O. Edmeades, M. Bänziger, H.R. Mickelson, C.B. Pena-Valdiva (Eds.), Developing Drought and Low N-Tolerant Maize. Proc. Symposium, March 25-29, 1996. CIMMYT, El Batan, Mexico. Mexico, D.F.

[31] Dawson, J.C., Huggins D.R. and Jones S.S. (2008) Characterizing nitrogen use efficiency in natural and agricultural ecosystems to improve the performance of cereal crops in low-input and organic agricultural systems. Field Crop Res 107:89-101.

[32] Delacy, I.H., K. Basford, M. Cooper, M. Bull, J.K. Maclaren, 1996 Analysis of multienvironment trials-An historical perspective. pp. 39-124. In: M. Cooper, G.L. Hammer (Eds.), Plant adaptation and crop improvement, CAB International.

[33] Desai, R.M., Bahatia C.R. (1978). Nitrogen uptake and nitrogen harvest index in durum wheat cultivars varying in their grain protein concentration. Euphytica. 27: 561-566.

[34] Di Fonzo, N., Motto M., Maggiore T., Sabatino R. and Salamini F.(1982). N-uptake, translocation and relationships among $\mathrm{N}$-related traits in maize as affected by genotype. Agronomie 2:789-796.

[35] El Bassam, N. (1998). A concept of selection for 'low-input' wheat varieties. Euphytica 100:95-100.

[36] FAO STAT (2011). Food and Organization of the United Nations, Statistics Division. Available online at: http:// www.faostat.fao.org. (assessed 01 April 2015).

[37] Geleto, T., Tanner, D.G., Mamo, T., Gebeyehu, G., 1995. Response of rain fed bread and durum wheat to source level and timing of nitrogen fertilizer on two Ethiopian vertisole S. I. yield and yield components. Comm. in Soil Sci. and Plant Analysis, 26:1773-1794.

[38] Gorny, A.G. and Ratajczak D. (2008). Efficiency of nitrogen and phosphorus utilization in progenies of factorial crosses between European and exotic cultivars of spring barley. J Appl Genet 49:349-355.

[39] Gorny, A.D. and Sodkiewicz T. (2001). Genetic analysis of the nitrogen and phosphorus utilization efficiencies in mature spring barley plants. Plant Breed 120:129-132. 


\section{American Research Journal of Agriculture, Volume 1, Issue 3, 2015}

ISSN 2378-9018

[40] Gorny, A.G., Banaszak Z., Lugowska B. and Ratajczak D. (2011). Inheritance of the efficiency of nitrogen uptake and utilization in winter wheat (Triticum aestivum L.) under diverse nutrition levels. Euphytica. 77: 191-206.

[41] Griffing, B. (1956). Concept of general and specific combining ability in relation to diallel crossing system. / Aust. J. Biol. Sci. 9: 463-493.

[42] Hallauer, A.R., J.B. Miranda, 1988 Quantitative genetics in maize breeding. 2nd ed. Iowa State University Press, Ames, USA.

[43] Kling, J.G., S.O. Oikeh, H.A. Akintoye, H.T. Heuberger, W.J. Horst, 1997 Potential for developing N use-efficient maize for low input agricultural systems inthe moist savannas of Africa. pp. 490-501. In: G.O. Edmeades, M. Bänziger, H.R. Mickelson, C.B. Peña-Valdivia (Eds.), Developing Drought and Low-N Tolerant Maize. CIMMYT, Mexico, D.F., El Batan,Mexico 25-29 March 1996.

[44] Lafitte, H.R., G.O. Edmeades, 1994 Improvement for tolerance to low soil nitrogen in tropical maize. III. Variation in yield across environments. Field Crops Res. 39: 27-38.

[45] Lafitte, H.R., G.O. Edmeades, 1995 Association between traits in tropical maize inbred lines and their hybrids under high and low soil nitrogen. Maydica 40: 259-267.

[46] Laperche, A., Brancourt-Hulmel M., Heumez E., Gardet O. and Le Gouis J. (2006). Estimation of genetic parameters of a $\mathrm{DH}$ wheat population grown at different N stress levels characterized by probe genotypes. Theor Appl Genet 112:797-807.

[47] Le Gouis, J, Be'ghin D, Heumez E, Pluchard P (2000). Genetic differences for nitrogen uptake and nitrogen utilization efficiencies in winter wheat. Eur. J. Agron. 12:163-173.

[48] Le Gouis, J, Be'ghin D, Heumez E, Pluchard P (2002). Diallel analysis of winter wheat at two nitrogen levels. Crop Sci. 42:1129-1134.

[49] Medici, L.O., Pereira MB, Lea P.J., Azevedo R.A. (2004) Diallel analysis of maize lines with contrasting responses to applied nitrogen. J Agric Sci 142:535-541.

[50] Meseka, S.K., A. Menkir, A.E.S. Ibrahim, S.O. Ajala, 2006 Genetic analysis of performance of maize inbred lines selected for tolerance to drought under low nitrogen. Maydica 51: 487- 495.

[51] Mosisa, W., 2005 Genetic and Crop-Physiological basis of Nitrogen Efficiency in Tropical Maize: Field Studies-University of Hannover.

[52] Presterl, T., Groh S., Landbeck M., Seitz G., Schmidt W. and Geiger H.H. (2008). Nitrogen uptake and utilization efficiency of European maize hybrids developed under conditions of low and high nitrogen input. Plant Breed 121:480486.

[53] Singh R.K., B.D. Chaudhary, 1985 Biometrical Methods in Quantitative Genetics Analysis. 2nd ed. Kalyani Publishers,New Delhi, India.

[54] Steel, R.G.D., Torrie J.H. and Dickey D. (1997). Principles and Procedure of Statistics. A Biometrical Approach 3rd Ed. McGraw Hill BookCo. Inc., New York. pp. 352-358.

[55] Wolfe, M.S., Baresel J.P., Desclaux D., Goldringer I., Hoad S., Kovacs G., Lo“schenberger F., Miedaner T., Østergard H., Lammerts van Bueren E.T. (2008). Developments in breeding cereals for organic agriculture. Euphytica 163:323-346.

[56] Yildirim, M., Bahar B., Genc I., Korkmaz K., Karnez E. (2007) Diallel analysis of wheat parents and their F2 progenies under medium and low level of available $\mathrm{N}$ in soil. J Plant Nutr 30:937-945. 